\title{
Development of Quality Assurance System for Academic Programs and Courses Reports
}

\author{
Sahar A. El_Rahman ${ }^{1,2}$ \\ ${ }^{1}$ Faculty of Engineering-Shoubra / Electronics, Computers Systems \& communication - Electrical Department, Cairo, \\ Egypt \\ ${ }^{2}$ Princess Nourah Bint Abdulrahman University/Department of Computer Science, Riyadh, 11487, Saudi Arabia \\ Sahr_ar@yahoo.com \\ Bashayer A. Al-Twaim \\ Imam Mohammad Bin Saud Islamic University/Department of Information Systems, Riyadh, 11487, Saudi Arabia \\ Baaltwaim@imamu.edu.sa
}

\begin{abstract}
This paper aims to review a proposed Quality Assurance system (QA) which suggests developing the internal quality assurance system of academic programs at the College of Computer and Information Sciences (CCIS), Princess Nourah Bint Abdulrahman University (PNU), Riyadh, Kingdom of Saudi Arabia (KSA), by replacing the existing paper-based QA System into a web-based system. In general, the QA system will work as: providing users the required NCAAA (National Commission for Academic Accreditation and Assessment) reports' forms to be filled. Then, the proposed QA system will gather forms and generates completed reports. At the same time, it provides them to the decision makers. The proposed QA system will allow decision makers to approve reports and view gathered information in many views in which will facilitate the making decision processes in continuing improvement of the educational processes and outcomes. Also, QA system can be extended and applied to other PNU colleges. After that, it can be applied to all KSA universities.
\end{abstract}

Index Terms-Academic Accreditation, Electronic Systems, NCAAA, Program Report, Quality Assurance

\section{INTRODUCTION}

We live in a world have everyday changes in information and communication technologies (ICT). These changes are largely related to education, and so the introduction of ICT in institutions of higher education, clearly changing the way it is implemented [1]. Today, with the improvement of technology and globalization, there is intense competition between institutions to be outstanding [2]. ICT is currently used effectively in libraries, research and development, as a communication medium, and for teaching and learning. A unique contribution to these processes and providing services to people at diverse locations is being made by internet [3].

Education is an essential tool for nation's building. However, the quality assurance has become an increasingly important factor in higher education recently. Specifically, the quality unit at College of Computer and
Information Science (CCIS), Princess Nourah Bint Abdulrahman University (PNU), is seeking for improving the learning outcomes at the three academic programs that offered by college. Furthermore, quality unit is facing difficulties with the existing Quality Assurance (QA) system at the QA Unit in the college. This paper will review the proposed quality assurance system which suggests developing the internal quality assurance system of academic programs at the College by replacing the existing paper-based QA system into a web-based system.

"Quality is the totality of features and characteristics of a product or service that bear on its ability to satisfy stated or implied need" [4]. "Dictionary of Education" explanation: "The quality of education is the assessment level and effectiveness of education,". The main body of higher education service quality evaluation is the learners and their families, mainly. The object of higher education service quality evaluation is the effect and process of educational services. Evaluation methods different according to different evaluation purposes; the learners' satisfaction is the main indicator to service quality evaluation of higher education [5].

Also, Quality Assurance (QA) is defined as system documents procedures with the aim of ensuring that the overall process meets specified objectives and to demonstrate that quality is a managed outcome [6]. It guarantees Quality Assurance in Higher Education which means the processes of maintaining standards and ensuring students have the best possible experience at university or college, learning outcomes which are the collection of knowledge, skills, and values that student will gain upon completion of a course, a span of several courses, or a degree program. So, the institute can be accredited where Accreditation: The formal certification by a recognized authority that an institution or program meets required standards [7].

\section{A. Problem Statement}

In particular, the old system that used at the college was a paper-based system, which is a time and effort consuming for QA unit and faculty members. QA unit at the college send and receive reports manually to/from 
faculty members. Afterwards, the faculty members fill these reports according to courses they taught during semester, and then submit the whole educational package including reports to QA unit at the end of each semester. Therefore, system processes were not effective. Recently, QA unit developed the process of sending and receiving reports in electronic format, as MS Word files, saved them in CDs by faculty members and handed them to QA unit. By these new changes, faculty member's time and effort is saved, but there are still problems with QA unit. On compilation of receiving reports, there is a still tedious process which is formulated in finding statistics, gathering results and providing them to the college decision makers.

\section{B. Proposed Solution}

One of suggestions to solve the previously reviewed problem is to build an internal system prototype of QA for CCIS to facilitate the communication between QA unit and the faculty staff to ensure the quality of academic programs. Moreover, the proposed system will replace the existing paper-based QA system at CCIS, PNU to a web-based system which will facilitate the QA unit processes from the moment of dissemination reports to academic faculty members until gathering information and generating reports' results. Also, it will help to decrease faculty member's time and effort that spent in completing reports.

\section{BACKGROUND INFORMATION AND RELATED WORK}

\section{A. Background Information}

Quality assurance is a comprehensive term used in different fields like industrial, agricultural, and commercial also it can be directed towards education as an entity. In contrast, Quality as a concept was a 20th century phenomenon that had its origin in the industry and management. Moreover, any talk related to quality assurance should starts by clarifying the terms 'quality' and 'quality assurance'. The word quality comes from the Latin word 'qualis' which means 'what kind of'. It ranges from meaning standard to excellence and both are deeply rooted in their respective values operational in individual and institutional. Quality assurance concept entails the supplier and consumer and the various activities put in place to produce quality products and services [8].

As more and more people over the world participate in higher education; issues of quality and quality assurance have begun to get more central position. Having quality and standards means everyone can have confidence in their degree and education. Standards should not vary from one higher education provider to another.

Quality assurance aims to prevent quality problems and ensure that only approved products reach the customer. In general, the most important job of quality assurance is to safeguard quality and standards in universities and colleges, so that students have the best possible learning experience. Moreover, achieving high standards has been always important, but there are a number of recent developments that make it even more necessary. The international reputation of graduates from any country will depend on standards at all institutions within country, not just a small number of major universities.

Everyone should be involved in the improvement process; quality can only be improved by those doing the job. However, help and support is needed, and arrangements have to be made for reporting, accountability, and verification that quality is achieved. Within institutions quality assurance units (QAU) are established, reporting to senior management, and assisted by a quality committee drawn from all sections of the institution [7]. Quality Assurance units (QAU) in higher education institutions are playing an important role in most of the countries that have established commissions of accreditation and quality assurance. The role of (QAU) is to ensure that high standards within teaching and learning processes for undergraduate programs are recognized and rewarded, and problems can be identified and addressed [9].

Until 2004, higher education institutes in Saudi Arabia required no accreditation. Rapid growth in the number of post-secondary institutions necessitated the creation of a government agency for quality assurance of higher education [10].

According to Ministry of higher education at Kingdom of Saudi Arabia official website, NCAAA was established in 2003, NCAAA is governmental body acting under the auspices of the Higher Council of Education. It has the responsibility for academic accreditation in higher education institutions. NCAAA is aiming to upgrade the quality of private and governmental higher education to ensure clarity and transparency [10]. On the other hand, getting ready for academic accreditation can be a quite challenging task, with many obstacles and challenges ranging from understanding the processes and developing objectives to establishing appropriate assessment mechanisms. In order for program accreditation to be successful, it is essential that the processes are fully supported by the whole institute from first year through to the senior year.

\section{B. Related Work Survey}

There were two of similar systems compared with QA system as shown in Table 1 They were compared according to the problem that they solved, targeted users and system domain, their features and output and finally their limitations.

\section{SYSTEM ANALYSIS}

There are two methods used during the process of gathering system's requirements and data which are interview and questionnaire besides studying the formal documents that provided by NCAAA [7]. Sample of people who will be using the proposed QA system were interviewed during the information gathering stage to find their needs in order to determine the system requirements. On the other hand, the questionnaire was prepared in order to gather some information about QA system which 


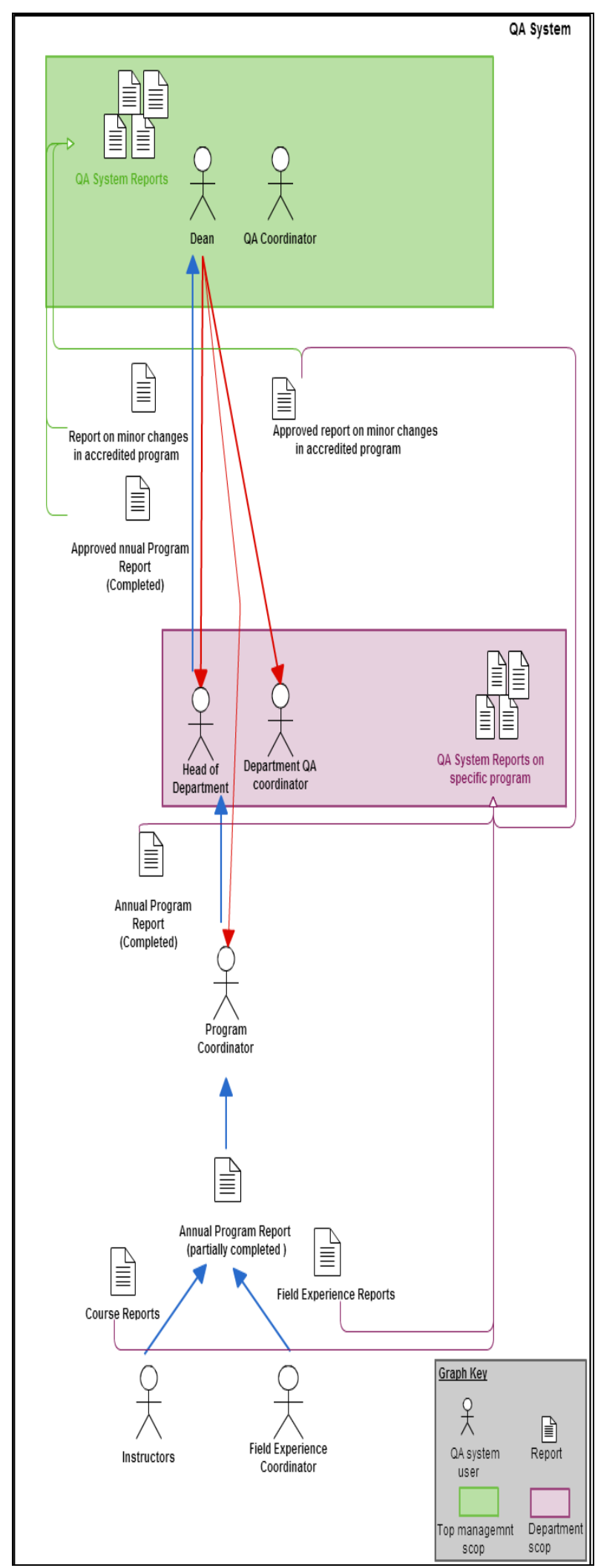

Fig. 1. QA system reports and user's interactions.

will be developed. The questionnaire was distributed over 10 of faculty members and QA unit members at the three departments of CCIS in PNU who have a good knowledge and experience about the QA system. From these analysis is found that there is a need for converting the existing manual QA system into an electronic system.
Moreover, the QA web-based system should be provides an easy way for users to fill QA reports in a user friendly interface within a period of time usually at the end of each semester. Also, the proposed QA system shall facilitate the processes of gathering and providing information to faculty members. After analyzing the requirements which have been gathered from the questionnaire, interview and formal documents information are extracted to find what necessary data to be modeled and stored. Moreover, the approach that used on analyzing and designing the proposed QA system is Object-Oriented approach. For simplicity and to understand the proposed QA system well, Fig. 1 shows how QA reports and users are interacting with each other.

\section{SYSTEM DESIGN}

Based on the functionality of the proposed QA system, the architecture that will be used is Client/Server architecture. As Fig. 2 shows, using the "Client/Server Model", there are three layers that composed together which are : client layer, server layer, and data layer. The client layer contains the interface which will be implemented in the proposed QA system by HTML and java scripts languages and for the user to request a process from the server layer we will use an ASP.net language. On the other hand, the server layer will handle the request by performing an SQL query and retrieve the data from data layer which contains the QA database such as equipment, staff and building data that will be stored in relational database. Also, the QA database interacts with the relevant data files, and responds to the requests. Moreover, Client/Server model selected because the proposed QA system is web-based system and this architecture excels in flexibility, easy to add new servers or upgrade existing servers and user independence.

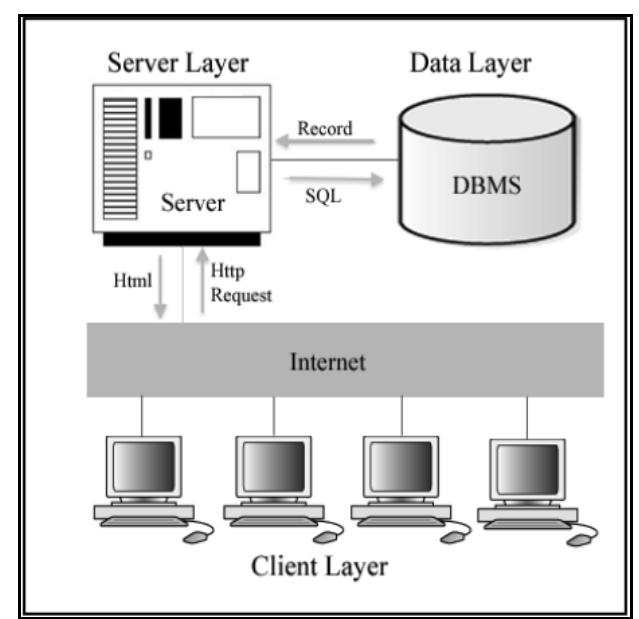

Fig. 2. Client/Server architecture

As the object oriented approach is used on building the proposed QA system, the object model had been chosen where the system is decomposed into interacting object as the Fig. 3 shows there are four objects that are interacts with each others. 
Table 1. Proposed and Similar System Comparison

\begin{tabular}{|c|c|c|c|}
\hline & QA system & $\begin{array}{l}\text { Quality Assurance } \\
\text { Checklist [11] }\end{array}$ & $\begin{array}{c}\text { Quality } \\
\text { Assurance Unit } \\
\text { System [12] }\end{array}$ \\
\hline $\begin{array}{l}\text { Dू } \\
\frac{1}{0} \\
0 \\
\frac{1}{0} \\
\frac{0}{0} \\
0 \\
0\end{array}$ & $\begin{array}{l}\text { Facilitate filling } \\
\text { QA reports } \\
\text { forms, gathering } \\
\text { information and } \\
\text { generates results } \\
\text { and statistics } \\
\text { process } \\
\text { Replacing the } \\
\text { paper-based QA } \\
\text { system into web- } \\
\text { based system. }\end{array}$ & $\begin{array}{l}\text { Quality assurance } \\
\text { checklist form for } \\
\text { evaluating courses } \\
\text { used as assistance } \\
\text { with the } \\
\text { development of } \\
\text { online courses and } \\
\text { course materials. }\end{array}$ & $\begin{array}{l}\text { Monitoring the } \\
\text { annual } \\
\text { performance of } \\
\text { education } \\
\text { processes } \\
\text { including } \\
\text { students' } \\
\text { performance using } \\
\text { web platform. }\end{array}$ \\
\hline 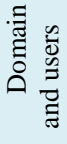 & $\begin{array}{l}\text { Faculty members } \\
\text { of CCIS, PNU. }\end{array}$ & $\begin{array}{l}\text { Faculty members of } \\
\text { Central of Michigan } \\
\text { University Global } \\
\text { Campus. }\end{array}$ & $\begin{array}{l}\text { QA unit of Anglia } \\
\text { Ruskin } \\
\text { University. }\end{array}$ \\
\hline 莺 & $\begin{array}{lr}\text { Provides } & \text { reports } \\
\text { forms } & \text { and } \\
\text { generates reports } \\
\text { and statistics } \\
\text { based on users' } \\
\text { entry. }\end{array}$ & $\begin{array}{l}\text { Provides } \\
\text { evaluation forms for } \\
\text { online courses and } \\
\text { generates reports } \\
\text { based on users' } \\
\text { entry. }\end{array}$ & $\begin{array}{l}\text { Works as a } \\
\text { subsystem of } \\
\text { overall QA } \\
\text { system in which } \\
\text { gather information } \\
\text { from other QA } \\
\text { subsystems and } \\
\text { extracts statistics. }\end{array}$ \\
\hline 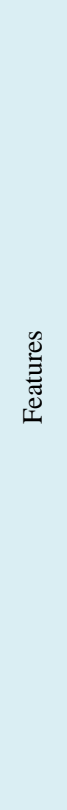 & $\begin{array}{l}\text { - } \\
\text { notification when } \\
\text { the time for } \\
\text { submitting } \\
\text { reports is come. } \\
\text { - Using popular } \\
\text { social networks } \\
\text { (Face book, } \\
\text { Twitter) for } \\
\text { publishing their } \\
\text { news. } \\
\text { - Compatibility } \\
\text { with different } \\
\text { internet } \\
\text { browsers. } \\
\text { - } \\
\text { statistics provides } \\
\text { different formats. }\end{array}$ & $\begin{array}{lr}\text { - Using popular } & \text { pocial } \\
\text { networks } \\
\text { (Face } & \text { book, } \\
\text { Twitter) } & \text { for } \\
\text { publishing } & \text { their } \\
\text { news. } & \\
\text { - They provide } \\
\text { FAQ (Frequently } \\
\text { Asked Questions). } \\
\text { - Compatibility with } \\
\text { different internet } \\
\text { browsers. }\end{array}$ & $\begin{array}{l}\text { - Integration with } \\
\text { other quality } \\
\text { assurance } \\
\text { subsystems such } \\
\text { as Student } \\
\text { Experience } \\
\text { Survey (SES). } \\
\text { - Export the } \\
\text { required data to } \\
\text { separate Excel } \\
\text { file. } \\
\text { - Help function is } \\
\text { provided through } \\
\text { documents and } \\
\text { system that } \\
\text { screenshots that by } \\
\text { explain step by to use } \\
\text { step how to } \\
\text { system. } \\
\text { - Ability to query } \\
\text { data from many } \\
\text { dimensions such } \\
\text { as by course, level } \\
\text { and selected } \\
\text { sections. }\end{array}$ \\
\hline . & $\begin{array}{l}\text { - Initially, system } \\
\text { will be for the } \\
\text { quality assurance } \\
\text { of academic } \\
\text { programs and } \\
\text { courses in CCIS, } \\
\text { PNU only. }\end{array}$ & $\begin{array}{lr}\text { - Built } & \text { for } \\
\text { university } & \text { online } \\
\text { courses only. }\end{array}$ & $\begin{array}{l}\text { - Statistics are } \\
\text { provided only in } \\
\text { forms of tables. }\end{array}$ \\
\hline
\end{tabular}

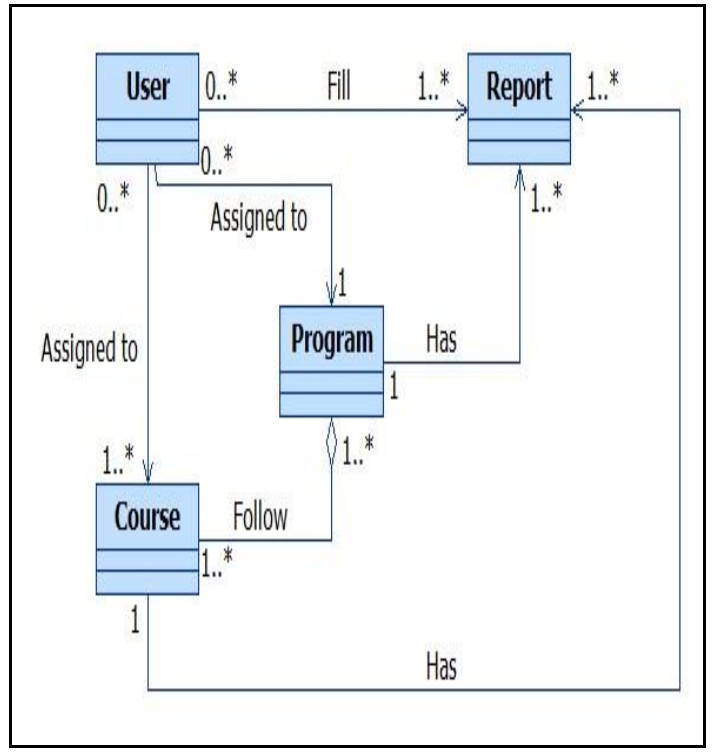

Fig. 3. Object Decomposition for QA System

\section{SYSTEM IMPLEMENTATION AND TESTING}

\section{A. Implementation}

The only hardware requirement needed to operate QA system is the PC machine and optionally printer to print system reports and scanner to attach documents if it's necessary. Besides the hosting site, the system programmed using HTML, ASP.net, C\#, CSS, SQL, and JAVA SCRIPT using Microsoft web Developer and MS SQL Server. On the other hand, the user interface of the proposed QA system was designed to accomplish two main design principles; simplicity, and usability Fig. 4 reveals the home page of QA system when user log in to the system, after user logged into the system a dashboard will be appeared which contains a menu help in navigating system and reaches all of its features such as filling report forms, view, manages courses and users, view generated results of reports and statistics.

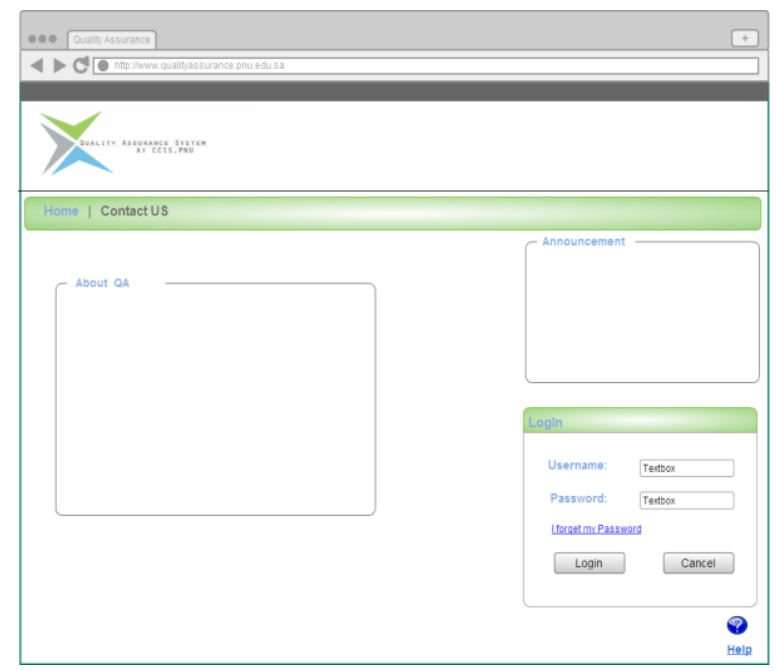

(a) QA Home Page 


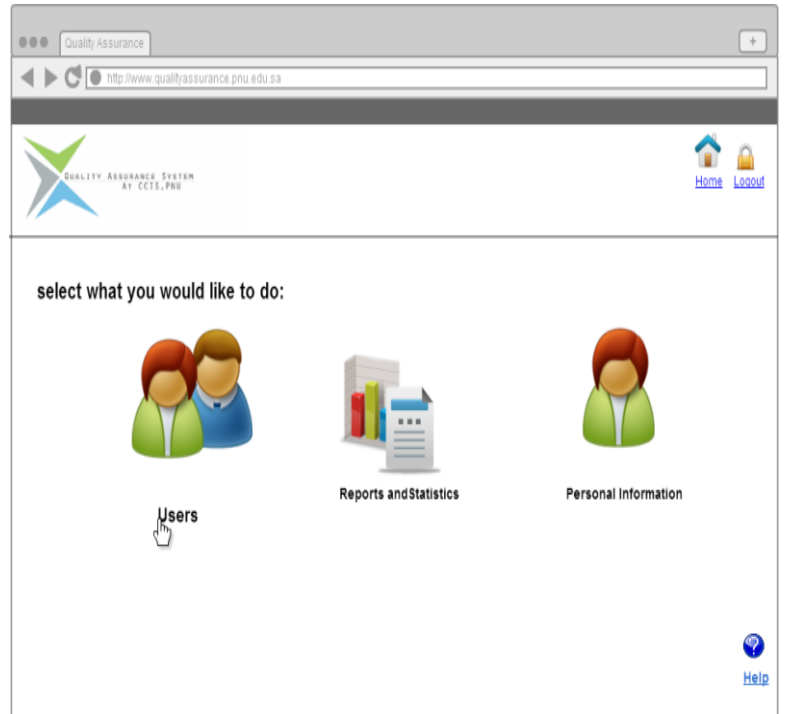

(b) College QA Coordinator Main Page

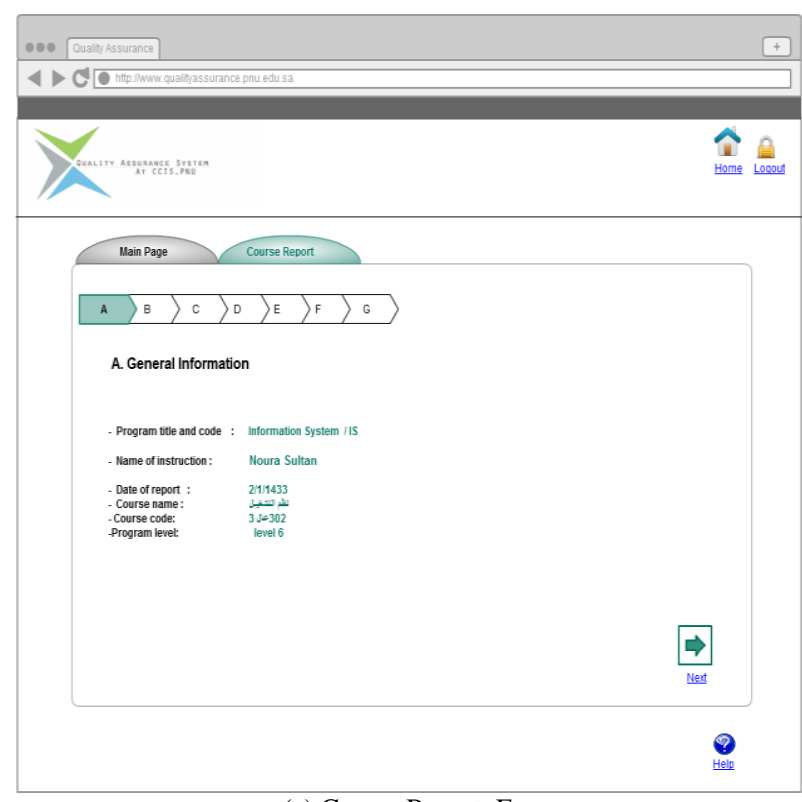

(c) Course Report Form

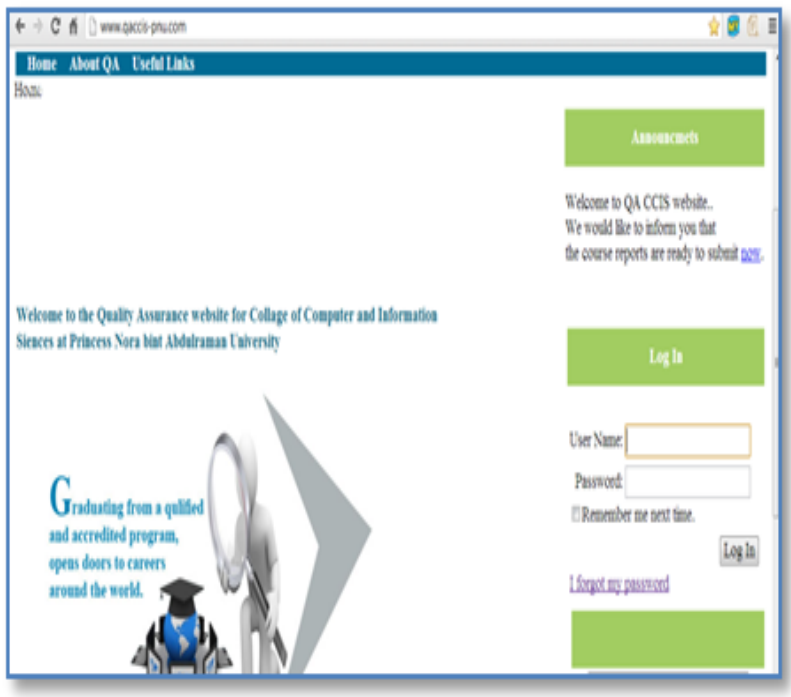

(d) QA Main Page Displaying Log In Form.

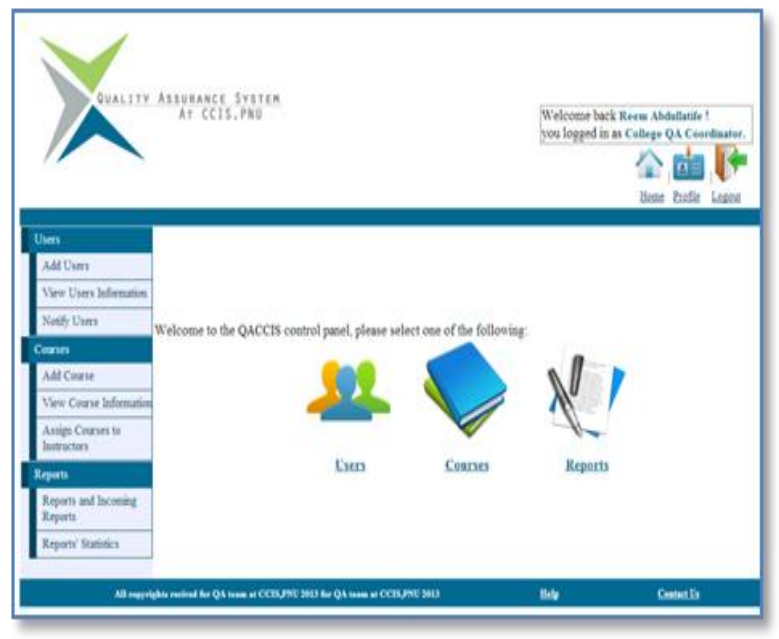

(e) Home Page of College QA Coordinator (Administrator).

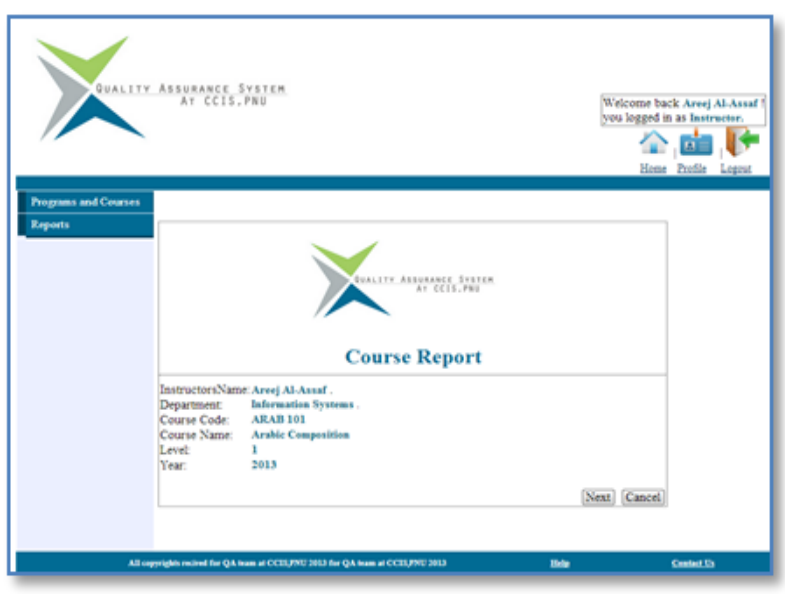

(f) Reports Form.

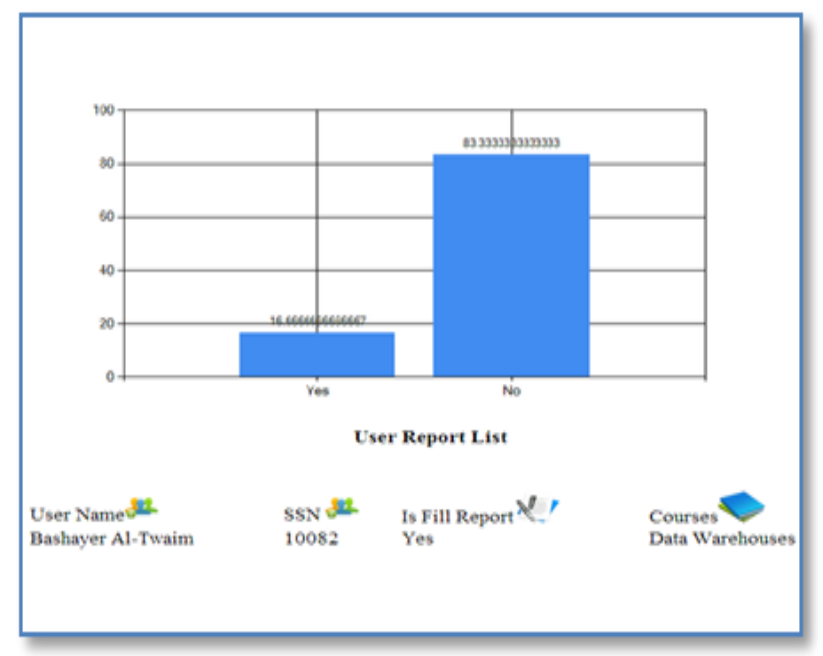

(g) Statistics screen.

Fig. 4. Main QA System Screens

\section{B. Testing}

The testing strategy that had been used in QA system is seeking for meeting its desired specifications and other requirements. Furthermore, the testing scope will cover 
the main features provided by the QA system to the user. In brief, testing strategy starts by conducting unit testing on every single function. After testing each function as it is scheduled and shown in Table 2, testing moved forward linking the pages together one by one and put system function all together performing integration testing. Finally, performance and acceptance testing are performed to determine whether or not a QA system satisfies its acceptance criteria.

Test results that preformed to the QA system achieves all the requirements mentioned in advance and all the desired goals. The QA system satisfies users by saving users time and effort. In addition, it allows the user to view the programs and It's levels, and views each course for that level with the possibility of filling and sending reports with simple interfaces.

QA System is able to perform the main functions provided by fully. Moreover, reports workflow runs in an integrated manner from the moment of fill to receive the other party and the Display the results of statistics.QA system will generate results and statistics from these reports completed for those responsible for decisionmaking in college. A system will be capable of being changed throughout its life. Also, the system can be modified to adapt to different devices and platforms because of its compatibility and flexibility.

\section{CONCLUSION}

The quality assurance has become an increasingly important factor in higher education. In addition, it is important to the institutions to meet the quality assurance standards to be recognized by government and reaches the global accreditation. In conclusion, this project has achieved some features and functionalities that the QA system provides. The QA system is established to deliver better services of quality program to College of Computer and Information Sciences (CCIS), in terms of developing and replacing the existing QA system into web-based system. QA system provides processes that will save users' time and efforts. Furthermore, QA system requires from users to enter and fill their own reports, and then it will generate the results and statistics from these completed reports for those responsible for making decisions in the college. QA system will help to measure the quality of educational programs and make an educational environment effective and an efficient based on quality assurance standards adopted.

\section{ACKNOWLEDGMENT}

The authors would like to thank all the participants involved into QA system development at CCIS, PNU especially to Arwa Al-Sa'ad, Amal AlRoshood, Randah AlQahtani and Sabreen AlDossari.
Table 2. Features to be Tested

\begin{tabular}{|c|c|}
\hline Feature & Description \\
\hline $\begin{array}{l}\text { Log } \\
\text { In/logout. }\end{array}$ & $\begin{array}{l}\text { Test functionality of log in and logout features } \\
\text { which are allowed for authenticated system } \\
\text { users. }\end{array}$ \\
\hline $\begin{array}{l}\text { Password } \\
\text { Recovery. }\end{array}$ & $\begin{array}{l}\text { Test functionality of recover password feature } \\
\text { which is enable user to get new password } \\
\text { when he/she forget. }\end{array}$ \\
\hline Add User. & $\begin{array}{l}\text { Test functionality of add user feature which is } \\
\text { enable admin to add new users to QA System. }\end{array}$ \\
\hline Add Course. & $\begin{array}{l}\text { Test functionality of add course feature which } \\
\text { is enable admin to add new course to QA } \\
\text { System. }\end{array}$ \\
\hline $\begin{array}{l}\text { Assign } \\
\text { course } \\
\text { Instructor. }\end{array}$ & $\begin{array}{l}\text { Test functionality of assign course to } \\
\text { Instructor feature which is enable admin to } \\
\text { assign course to specific Instructor. }\end{array}$ \\
\hline Notify User. & $\begin{array}{l}\text { Test functionality of notify user feature which } \\
\text { is enable admin to notify user by email. }\end{array}$ \\
\hline $\begin{array}{l}\text { Update } \\
\text { Personal } \\
\text { Information. }\end{array}$ & $\begin{array}{l}\text { Test functionality of update Personal } \\
\text { Information feature which is enable user to } \\
\text { edit her/his own information. }\end{array}$ \\
\hline $\begin{array}{l}\text { View } \\
\text { Programs and } \\
\text { Courses. }\end{array}$ & $\begin{array}{l}\text { Test functionality of view programs and } \\
\text { courses feature which is enable user view } \\
\text { course information. }\end{array}$ \\
\hline $\begin{array}{l}\text { Fill and } \\
\text { Submit } \\
\text { Course } \\
\text { Report. }\end{array}$ & $\begin{array}{l}\text { Test functionality fill course report feature } \\
\text { which is enable introducer to send report to } \\
\text { program coordinator. }\end{array}$ \\
\hline $\begin{array}{l}\text { Approve And } \\
\text { Disapprove } \\
\text { Report. }\end{array}$ & $\begin{array}{l}\text { Test functionality of approve or reject feature } \\
\text { which is enable dean to select status of } \\
\text { incoming reports. }\end{array}$ \\
\hline $\begin{array}{l}\text { View } \\
\text { Report's } \\
\text { Statistics. }\end{array}$ & $\begin{array}{l}\text { Test functionality view report's statistics } \\
\text { which is enable admin to view results of } \\
\text { incoming reports. }\end{array}$ \\
\hline
\end{tabular}

\section{REFERENCES}

[1] Mirjana Kocaleva, Igor Stojanovic and Zoran Zdravev, " Model of e-Learning Acceptance and Use for Teaching Staff in Higher Education Institutions", Copyright (C) 2015 MECS I.J. Modern Education and Computer Science, 2015, 4, 23-31. http://www.mecs-press.org/

[2] Mei Yean ONG, Balakrishnan Muniandy, Saw Lan ONG, Keow Ngang TANG, Kia Kien PHUA, "Comparing the Acceptance of Key Performance Indicators Management Systems on Perceived Usefulness and Perceived Ease of Use in a Higher Education Institution in Malaysia", I.J.Modern Education and Computer Science, 2012, 10, 916. http://www.mecs-press.org

[3] Allah Nawaz, Muhammad Zubair Khan, "Issues of Technical Support for e-Learning Systems in Higher Education Institutions", I.J.Modern Education and Computer Science, 2012, 2, 38-44. http://www.mecspress.org/

[4] British Standards Institution BIS, 2012. BSI Standards. [online]. Available at: <http://www.bsigroup.com/ > [Accessed 13 January 2013].

[5] Liu Zhiqin, Fei Jianguo, Wang Fang and Deng Xin, " Study on Higher Education Service Quality Based on Student Perception", I.J. Education and Management Engineering 2012, 4, 22-27 . http://www.mecs-press.net

[6] Dawson, P., \& Palmer, G. (1995). "Quality management". Australia: Longman.

[7] The National Organization for Assessment and Accreditation, 2010. Organization Publication.[Online]. Available at: <http://www.ncaaa.org.sa/english/ astandardfront.aspx > [Accessed 27 November 2012]. 
[8] Mkpandiok, 2006. A. "Quality Assurance in Secondary Schools in Akwa Ibom State". Uyo: University of Uyo.

[9] Ministry of higher education, 2010. "National Commission for Academic Accreditation \& Assessment". [Online] Available at: < http://www.mohe.gov.sa/ en/aboutus/Institutions/Pages/academicccreditation.aspx $>$ [Accessed 1 December 2012].

[10] Abdul Rahman Al Mohaimeed, 2012. "Academic Accreditation Process: Experience of a Medical College in Saudi Arabia". International Journal of Health Sciences, 6(1), p.23

[11] Central Michigan University Global Campus, 2009. "CID Quality Assurance Checklist." [Online] Available at: <http://global.cmich.edu/cid/quality-checklist.aspx> [Accessed 13 January 2013].

[12] Anglia Ruskin University, 2011. "Quality Assurance Unit: Academic Appeals Unit". [Online] Available at: <http://web.anglia.ac.uk/anet/academic/appeals/ index.phtml > [Accessed 13 January 2013].

\section{Authors' profiles}

Sahar Abd El_Rahman was born in Cairo, Egypt, B.Sc. Electronics, Computer Systems \& communication, Electrical Engineering Department. Benha University, Shoubra Faculty of Engineering, Cairo-Egypt. M.Sc. in an AI Technique Applied to Machine Aided Translation, Electronic Engineering, Electrical Engineering Department, Benha University, Shoubra Faculty of Engineering, Cairo-Egypt, May2003. PHD. in Reconstruction of High-Resolution Image from a Set of Low-Resolution Images,
Electronic Engineering, Electrical Engineering Department, Benha University, Shoubra Faculty of Engineering, Cairo-Egypt in Jan2008.

She is ASSISTANT PROFESSOR from 2011 till now at Princess Nourah Bint Abdulrahman University/Department of Computer Science, College of Computer and Information System. Also, She is ASSISTANT PROFESSOR from 2008 till now at Electronics \& communication, and Computer Systems, Electrical Engineering Department, Faculty of Engineering, Shoubra,, Benha University, Cairo, Egypt. She was a LECTURE in the same location from 2003 and INSTRUCTOR in the same location in 1998. Her research interests include computer vision, digital image processing, Signal processing, information security and cloud computing.

Dr. Sahar A. El_Rahman is a member of IACSIT (International Association of Computer Science and Information Technology) since 2013.A member of IAENG (International Association of Engineers) since 2011.A member of the Egyptian Engineers' Syndicate since 1997.

Bashayer A. Al-Twaim Teaching Assistant at college of computer and information sciences, Imam Mohammed Bin Saud University, Riyadh, Saudi Arabia. She received her bachelor's degree in information systems from Princess Noruah Bint Abdulrahman University in 2013. Her fields of interest are: cloud computing, Natural language processing, and Data analysis and mining.

How to cite this paper: Sahar A. El_Rahman, Bashayer A. Al-Twaim,"Development of Quality Assurance System for Academic Programs and Courses Reports", IJMECS, vol.7, no.6, pp.30-36, 2015.DOI: 10.5815/ijmecs.2015.06.05 